\title{
Near Immunity to Rice Tungro Spherical Virus Achieved in Rice by a Replicase-Mediated Resistance Strategy
}

\author{
H. Huet, S. Mahendra, J. Wang, E. Sivamani, C. A. Ong, L. Chen, A. de Kochko, R. N. Beachy, and C. Fauquet
}

First, third, fourth, sixth, seventh, eighth, and ninth authors: ILTAB, (IRD-DPSC), TSRI, CAL7, 10550 N. Torrey Pines Road, La Jolla, CA 92037; and second and fifth authors: Malaysian Agricultural Research and Development Institute (MARDI), Kuala Lumpur, PO Box 12301, Malaysia. Current address of H. Huet: ARO, Volcani Center, PO Box 6, Bet-Dagan, 50250, Israel.

Current address of L. Chen: Novartis Agricultural Discovery Institute, 3050 Science Park Road, San Diego, CA 92121.

Current address of C. Fauquet: ILTAB/DDPSC, UMSL, Benton Hall, 8001 Natural Bridge Road, St. Louis 63121-4499.

Accepted for publication 1 July 1999.

\section{ABSTRACT}

Huet, H., Mahendra, S., Wang, J., Sivamani, E., Ong, C. A., Chen, L., de Kochko, A., Beachy, R. N., and Fauquet, C. 1999. Near immunity to rice tungro spherical virus achieved in rice by a replicase-mediated resistance strategy. Phytopathology 89:1022-1027.

Rice tungro disease is caused by rice tungro bacilliform virus (RTBV), which is responsible for the symptoms, and rice tungro spherical virus (RTSV), which assists transmission of both viruses by leafhoppers. Transgenic japonica rice plants (Oryza sativa) were produced containing the RTSV replicase (Rep) gene in the sense or antisense orientation. Over $70 \%$ of the plants contained one to five copies of the Rep gene, with integration occurring at a single locus in most cases. Plants producing anti- sense sequences exhibited significant but moderate resistance to RTSV $(60 \%)$; accumulation of antisense RNA was substantial, indicating that the protection was not of the homology-dependent type. Plants expressing the full-length Rep gene, as well as a truncated Rep gene, in the (+)sense orientation were $100 \%$ resistant to RTSV even when challenged with a high level of inoculum. Accumulation of viral RNA was low, leading us to conclude that RTSV Rep-mediated resistance is not protein-mediated but is of the cosuppression type. Resistance was effective against geographically distinct RTSV isolates. In addition, RTSV-resistant transgenic rice plants were unable to assist transmission of RTBV. Such transgenic plants could be used in an epidemiological approach to combat the spread of the tungro disease.
Rice tungro disease is one of the most severe virus diseases of rice and a significant threat to rice production in Southeast Asia (20), where outbreaks of the disease are sporadic and, therefore, difficult to control $(25,27)$. Rice tungro is a complex disease resulting from infection by two viruses: rice tungro bacilliform virus (RTBV), which is responsible for the symptoms, and rice tungro spherical virus (RTSV), which assists transmission of both viruses by the green leafhopper (GLH) vector Nephotettix virescens (23). The RTSV genome is a positive-sense single-stranded (ss) RNA encoding a large polyprotein, which is subsequently processed by a viral protease. The virus also produces two subgenomic RNAs (29). RTSV alone does not induce symptoms but does enhance the severity of RTBV symptoms in rice plants infected by both viruses (23). Tungro disease typically starts with RTSV infection, which precedes RTBV infection (35); once inoculum becomes available, the disease spreads through secondary infection, as viruliferous GLH transport the viruses from plant to plant within the field (1).

Most attempts to control rice tungro disease by classical breeding have not proved to be durable, because the improved rice varieties were bred for elevated resistant to the leafhoppers, rather than the viruses, and because the insects overcame resistance (13). Genetic engineering utilizing pathogen-derived resistance strategies has now been shown to successfully control many viruses in a variety of crops (5) and, thus, may also be effective against rice tungro disease.
The spread of disease depends on RTSV and secondary infection; therefore, we applied a pathogen-derived resistance strategy to produce transgenic rice with elevated resistance to RTSV. We showed previously that RTSV coat proteins provided significant protection, although moderate, when expressed as transgenes, resulting mainly in a delay of disease symptoms (31). The requirement for higher resistance led us to attempt replicase-mediated resistance (Rep-MR) strategies to control the disease.

In the past few years, many transgenic plants expressing Rep genes derived from different viruses have been tested in various plants. Resistance is usually strain specific and is often very high against the infecting virus particles as well as viral RNA $(4,28)$. Most Rep-MR seems to be related to the homology-dependent or cosuppression phenomenon by which RNA produced by the transgene or viral RNA from the invading virus is specifically degraded $(17,26)$. Alternatively, protein interaction may induce resistance by some mechanisms that are not yet clearly understood. More elaborate resistance mechanisms have been reported in the case of the resistance against cucumber mosaic virus, in which both Rep RNA and protein are apparently involved (19).

In this article, we describe the effect of expression of the RTSV replicase coding sequence in sense or antisense orientation, and demonstrate imported resistance against RTSV in virus-challenged transgenic rice plants. The possible use of such transgenic plants in the field and their impact on the tungro disease are discussed.

\section{MATERIALS AND METHODS}

Corresponding authors:

A. de Kochko; E-mail address: kochko@mpl.ird.fr

C. Fauquet; E-mail address: ILTAB@danforthcenter.org

Publication no. P-1999-0913-01R

(C) 1999 The American Phytopathological Society
Plasmids. Based upon the known sequence of RTSV RNA and the putative cleavage sites of the encoded polyprotein (29), specific primers were designed to amplify the Rep gene by reversetranscriptase polymerase chain reaction (RT-PCR) from purified RTSV particles (provided by the International Rice Research In- 
stitute, Los Baños, the Philippines). The forward primer provided an ATG initiation codon at the putative $5^{\prime}$ end of the Rep gene sequence (F-Rep: 5'-cggatccg atgTTGGTGCCCACATCTGTT-3' nucleotides 9,227 to 9,244 of the RTSV sequence, with a BamHI linker and a start codon shown in lowercase) and the reverse primer contained, in addition to the native stop codon, an introduced BamHI linker (RRep: 5'-cggatccgTTACACCTCCAAGTCAAGAA-3' reverse complement of nucleotides 10,917 to 10,936 of the RTSV sequence). After digestion with $\mathrm{BamHI}$, the intact gene was inserted at the corresponding site into a transformation vector between the maize ubiquitin promoter plus the first intron of the ubiquitin gene and the nopaline synthase (NOS) terminator. This gave rise to a sense (+) construct, pILTAB223, and an antisense (-) construct, pILTAB224.

Rice transformation. Transformation of calli, selection, and regeneration were performed as described by Chen et al. (10). Embryogenic calli of japonica rice (Oryza sativa L., cv. TP309) were bombarded using a helium-driven device (PDS-1000/He; Bio-Rad Laboratories, Hercules, CA). The plasmids described above were cobombarded with pMON410 (Monsanto Company, St. Louis), which contains the hygromycin phosphotransferase gene $(h p h)$ under the control of the cauliflower mosaic virus $35 \mathrm{~S}$ promoter for hygromycin selection of the transformed calli. The molar ratio of the plasmids used was 6:1 for Rep $h p h$. Transgenic plants containing the Rep gene in the (+)-sense and (-)-antisense orientation were regenerated after selection on hygromycin.

Plant characterization. All DNA extractions were carried out according to Dellaporta et al. (15). PCR was performed on total DNA extracted from hygromycin-resistant plantlets to confirm the presence of the RTSV Rep gene, using the same primers as those used for cloning the gene but without the BamHI linkers. The expected amplified fragment was 1,707 base pairs long.

Southern blots. Total DNA was extracted from rice plants that were PCR positive for the RTSV Rep gene. Approximately $3 \mu \mathrm{g}$ of DNA, undigested or digested with appropriate restriction enzymes, were loaded on a $0.8 \%$ agarose gel in Tris-borate-EDTA buffer. Restriction enzymes were chosen to cut the plasmid once outside the gene cassette $(B g l I I)$ or twice in order to isolate most of the cassette (BglII and $\operatorname{SmaI}(+)$ or $\operatorname{Sph} \mathrm{I}(-)$; no sites were available to isolate the entire cassette). After overnight transfer to nylon membrane (Hybond-N; Amersham, Piscataway, NJ) in 10× SSPE $\left(1 \times \mathrm{SSPE}\right.$ is $0.18 \mathrm{M} \mathrm{NaCl}, 10 \mathrm{mM} \mathrm{NaPO}_{4}$, and $1 \mathrm{mM}$ EDTA [pH 7.7]), a 1-h prehybridization and overnight hybridization were performed at $65^{\circ} \mathrm{C}$, using a hybridization buffer containing $1 \%$ bovine serum albumin, $1 \mathrm{mM}$ EDTA, $0.5 \mathrm{M} \mathrm{NaHPO}_{4}$ at $\mathrm{pH} 7.2$, and 7\% sodium dodecyl sulfate (SDS) (11). A PCR fragment representing the whole Rep gene was used as a probe after radiolabeling using the Prime-It II kit (Stratagene Inc., San Diego, CA).

Northern blots. Total RNA was isolated by a modified procedure based on Haffner et al. (18). Leaf tissues ground in liquid nitrogen were mixed with Tris-HCl (1 M, pH 9), extracted twice with phenol $(\mathrm{pH} 9)$, followed by two cycles of precipitation (the first with potassium acetate, $2 \% \mathrm{wt} / \mathrm{vol}$, and the second with $2 \mathrm{M} \mathrm{LiCl}$ ). After electrophoresis in agarose gels prepared in a morpholinepropanesulfonic acid-based buffer (formamide and formaldehyde being present only in loading solution), RNA was blotted to Hybond-N. Prehybridization and hybridization reactions were carried out as described above for Southern blots.

The truncated Rep gene present in line T147-3 was recovered using PCR with primers specific to the ubiquitin promoter (Ubi1) and NOS terminator (Nos). Ubi1 = 5'-GTCGATGCTCACCCTGTT-3' and Nos $=5^{\prime}$-GTAACATAGATGACACCGCG-3'.

The amplified fragment was directly sequenced on a 373A apparatus (Applied Biosystems, Inc., Foster City, CA) by means of Taq-mediated elongation with dye-labeled F-Rep and R-Rep primers described above.

Challenge inoculation against RTSV. Challenge of the plants by virus inoculation was conducted at the Malaysian Agricultural Research and Development Institute (MARDI), Kuala Lumpur,
Malaysia, in an insect-proof greenhouse as described by Sivamani et al. (31), with minor modifications. A first inoculation was performed with four RTSV viruliferous GLH on 14-day-old plantlets. Infection was analyzed by enzyme-linked immunosorbent assay (ELISA) 15 days later, immediately followed by a second inoculation with four GLH on ELISA-negative plants. A second ELISA was performed 12 to 14 days later, and a third assay 35 days after the second inoculation. In each experiment, a minimum of five TP309 control plants, and in some experiments five additional plants from indica variety Taichung Native 1 (TN1), were challenged simultaneously.

Double-antibody sandwich (DAS)-ELISA to detect RTSV. RTSV alone does not induce visible symptoms on infected rice plants; therefore, DAS-ELISA was performed on all challenged plants after each round of virus inoculation. Approximately $10 \mathrm{~cm}$ of the second leaf was homogenized with $1 \mathrm{ml}$ of phosphate-buffered saline buffer in a Meru Leaf and Shoot Press (Erich Polhane, Weingarten, Germany). A total of $100 \mu$ l of extract was added to microtiter plate wells, precoated for $4 \mathrm{~h}$ at $37^{\circ} \mathrm{C}$ with anti-RTSV antiserum, and incubated $4 \mathrm{~h}$ at $37^{\circ} \mathrm{C}$. Anti-RTSV polyclonal primary antibodies produced at MARDI against purified RTSV were used at 1:250 dilution in the DAS-ELISA. Anti-RTSV antibodies conjugated with alkaline phosphatase were added and placed at $4^{\circ} \mathrm{C}$ overnight, followed by the enzyme reaction assay. If, after the second ELISA, an inoculated plant showed an absorbance at $405 \mathrm{~nm}$ equal to a noninfected control, it was considered free of virus; if the absorbance was at least twice as high, the plant was considered infected.

\section{RESULTS}

Regeneration and characterization of plant lines containing (+)-sense Rep sequences. From cotransformation performed with the (+)-sense gene construct (pILTAB223), 16 plants were recovered after selection on hygromycin-containing medium. PCR analyses revealed that 13 regenerated plants $(81 \%)$ contained the Rep gene. All of the transgenic plants were morphologically normal and exhibited variable degrees of fertility (5 to $90 \%$ ).

$\mathrm{R} 1$ offspring of four of the most fertile lines $(>50 \%)$ were selected for preliminary studies on resistance to the virus. After a first set of challenge experiments, three lines giving promising results were further studied. Lines 147.4 and 147.8 each possessed the entire gene, while line 147.3 appeared to contain a truncated form of the Rep gene whose sequence showed that an internal deletion of 572 nucleotides had occurred toward the $3^{\prime}$ end of the gene, between nucleotides 10,254 and 10,824 of the RTSV genomic sequence. This deletion introduced a frame shift that prevented translation of the remaining downstream sequence of the gene (Fig. 1).

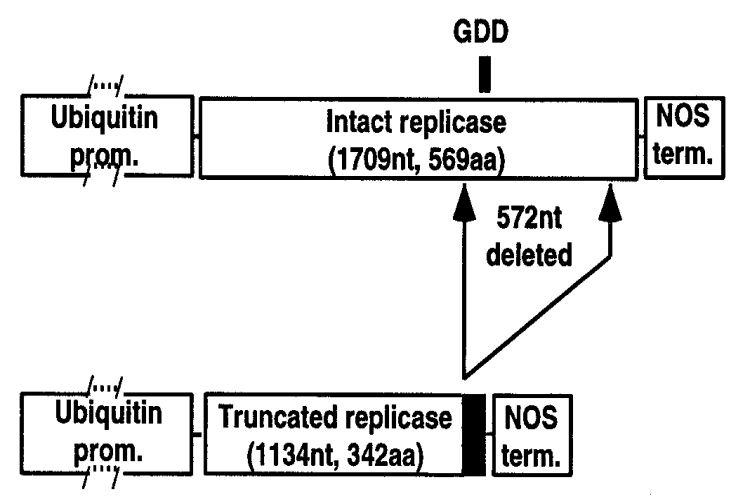

Fig. 1. Schematic representation of the intact and truncated form of the rice tungro spherical virus replicase gene as transferred to TP309 rice plants. The replicase gene is driven by the maize ubiquitin promoter (ubiquitin prom.) and terminated by the nopaline synthase terminator (NOS term.). Solid black indicates that this region was not properly translated due to a frame shift introduced by the deletion. 
This line has the potential to express a protein in which the Nterminal half of the protein is identical to the Rep, but lacks 191 amino acids from the $\mathrm{C}$-terminus, including the GDD sequence that is conserved in RNA polymerases (24).

Siblings from the R3 generation of the three selected lines were used for further greenhouse testing: lines 147.3 and 147.4 were found to be homozygous for the transgene as shown by PCR and all of the grown plants ( 9 and 22, respectively) contained the transgene. Line 147.8 was heterozygous, segregating at a 3:1 Mendelian ratio (19 PCR+/8 PCR-). Southern blot data showed line 147.3 to have integrated at least three copies of the transgene. Line 147.4 had at least two copies, while 147.8 contained a single copy (data not shown).

A Rep-specific antibody was not available; therefore, expression of the transgene was characterized only at the RNA level using northern blot hybridization assays. In each 147 line, (+)-sense RNA accumulation was low compared with the accumulation of (-)-sense RNA (Fig. 2).

Regeneration and characterization of plant lines containing (-)-sense Rep sequence. Transformation with the (-)-sense gene construct (pILTAB224) produced 31 regenerants. Twenty-two plants (71\%) were PCR positive for the Rep gene. No morphological abnormalities were detected among these plants. In a preliminary study, seven fertile lines ( $>50 \%$ fertility) were studied for resistance, followed by a more complete study of three lines. PCR-based analysis of the R1 plants showed that line 146.1 segregated in a 15:1 ratio (13 PCR+/1 PCR-), indicating probable transgene integration at two different genetic loci. Lines 146.6 and 146.7 segregated in a 3:1 ratio, compatible with integration of the transgene

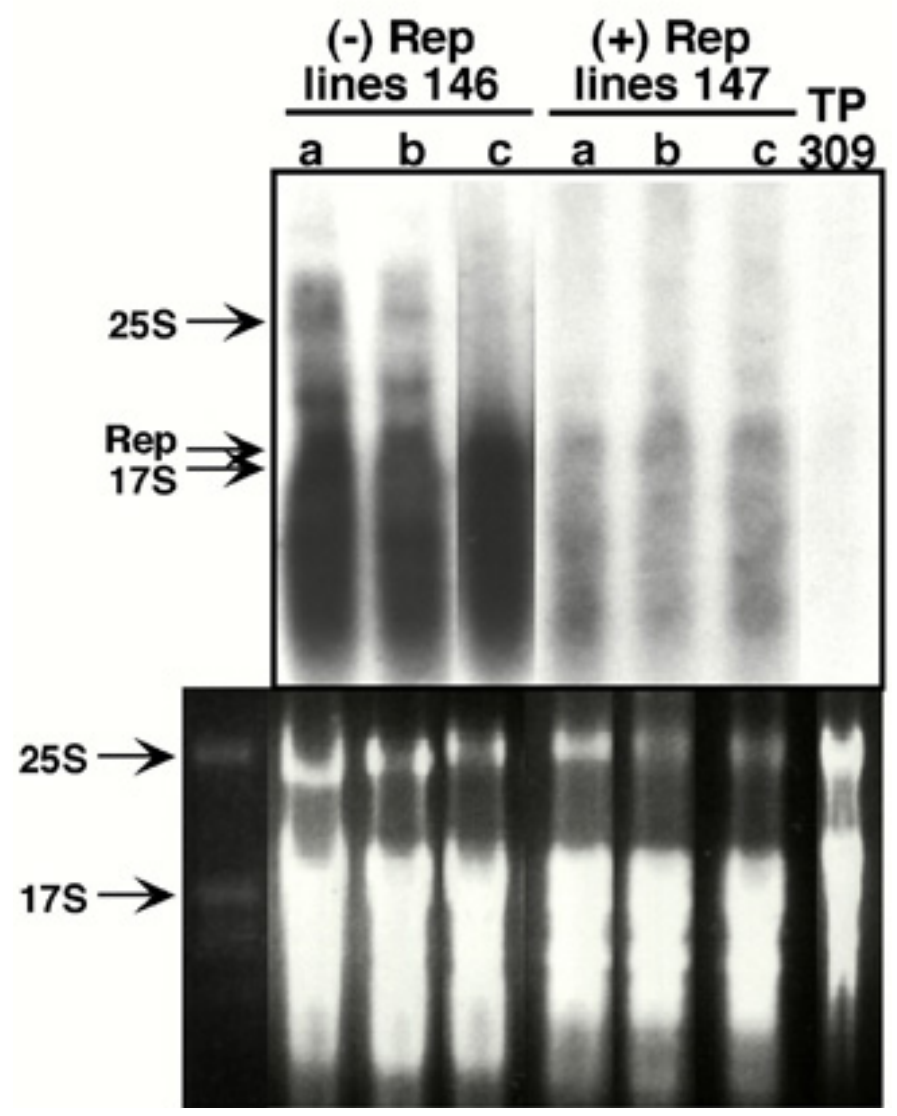

Fig. 2. Upper: RNA expression of transgenic plant lines. Northern blot analysis of total RNA $(20 \mu \mathrm{g})$ from the transgenic lines expressing the rice tungro spherical virus replicase in the antisense orientation (Rep (-)-sense, lines 146), in the sense orientation (Rep (+)-sense, lines 147), and from a nontransformed TP309 plant. Arrows indicate 25S and 17S rRNA and expected migration of the transgene transcript. Lower: Corresponding agarose gel lanes with the $25 \mathrm{~S}$ and $17 \mathrm{~S}$ rRNA indicated by arrows. copies at a single locus. All three plant lines contained the entire gene sequence and, according to Southern blot banding patterns, were estimated to have integrated at least four, three, and five copies of the (-)-sense Rep sequence for the plant lines 146.1, 146.6, and 146.7 , respectively.

Northern blot analysis showed that the level of RNA accumulation was comparable for the three lines and was higher than in lines 147 (Fig. 2). The migration anticipated for the gene transcript (Fig. 2 , arrow) gene-related sequences was associated with a poly-disperse group of molecules, indicating that the RNA was relatively unstable in comparison with ribosomal RNA.

Virus resistance of the (+)-sense Rep plant lines 147. RTSV infection was assessed by ELISA after each round of inoculation. A plant was considered resistant if ELISA was still negative after the second inoculation (e.g., absorbance at $405 \mathrm{~nm}$ inferior or equal to noninfected plant, $\leq 0.1)$. In all cases, infected plants showed high absorbance at $405 \mathrm{~nm}$ (0.4 to 1.6).

In preliminary screening of four lines for resistance to RTSV, PCR was not performed, but the number of virus-free segregating R1 progeny after two rounds of virus inoculation was recorded. Whereas all the nontransgenic control plants (TP309 and TN1) were infected, the transgenic plant line 147.14 showed $8 \%$ noninfected plants, while lines $147.3,147.4$, and 147.8 possessed 70,71 , and $56 \%$ resistant plants, respectively. Offspring from the R3 generation of each of these three lines were subsequently challenged with RTSV. PCR analyses were performed on each challenged R3 plant to confirm that it carried the transgene. All of the negative segregants for line 147.8 and the control TP309 were infected within 12 days of the second inoculation, whereas all of the PCR-positive plants were found to be free of virus 35 days after the second inoculation (Table 1).

In another experiment performed with 3-week-old R3 plantlets of line 147.3, using 5, 10, or 20 viruliferous GLH, none of the plants became infected (data not shown).

Resistance of the (-)-sense Rep lines 146. As described above, plants from the R1 generation of transgenic lines (not characterized by PCR) were challenged by inoculation with RTSV. The four lines $146.3,146.9,146.13$, and 146.21 exhibited between 14 and $26 \%$ resistant plants; line 146.6 exhibited 68\% resistant plants; and two lines, 146.1 and 146.7, were susceptible. Resistance assays were repeated with additional R1 offspring of the last three lines (146.6, 146.1, and 146.7). The last two lines, which were found to be susceptible, were further studied to determine if there was recovery from virus accumulation over longer time periods. All plants from lines 146.1 and 146.7 became infected after the second inoculation and no recovery was observed (Table 1). Line 146.6 showed a significant level of resistance, with $61 \%$ of plants remaining free of virus after the second inoculation and virus accumulation still not detected in $44 \%$ of the plants after an additional 2 weeks.

In all experiments, all the control plants were infected after the second round of inoculation (absorbance at $405 \mathrm{~nm} \geq 5 \times$ the value of noninfected plants).

Specificity of resistance. In the previous inoculation experiments, the plants were challenged with a RTSV isolate from Serdang in the central region of the Malaysian peninsula. To assess the specificity of resistance provided by the Rep gene, tungro isolates (mixtures of RTBV and RTSV) collected in different Malaysian areas were used to challenge the (+)-sense transgenic plant lines. Two isolates were obtained from the south peninsula (Johor; mild and severe), one from the northwest peninsula (Bukit Merah), and two from Borneo (Papar and Kota Belud). Healthy GLH were fed overnight on rice infected with the tungro isolates and then placed for overnight inoculation on five 10-day-old 147.4 plantlets at three to four GLH per plant. Although plants became infected with RTBV, indicating that the helper RTSV was indeed present in the source samples, all the transgenic plants were resistant to RTSV (data not shown).

RTBV transmission from RTSV-resistant plants. Transgenic plants from all of the resistant lines described above were inocu- 
lated with GLH fed previously on source plants known to contain both RTBV and RTSV. All of the plants became infected with RTBV but not with RTSV, except for one plant from line 146.6 and one from line 147.3, which were infected by both viruses. RTSV infection was expected for the "antisense" line because it showed about $60 \%$ resistant plants (Table 1), but was unexpected for 147.3 because, in a previous experiment, $100 \%$ of the plants were found to be resistant (Table 1). After infection, these plants were used as sources for further virus acquisition by GLH. GLH known to be RTSV viruliferous were used as a control. The insects were then left overnight on four TN1 plants (three GLH per plant). Virus transmission to TN1 plants was determined 2 weeks later by ELISA.

When GLH were fed on transgenic, RTSV-free plants infected by RTBV, they did not acquire or transmit any virus, whereas RTSV viruliferous GLH were able to do so (Table 2). Alternatively, when plants were infected by RTSV in addition to RTBV, both viruses were transmitted, regardless of whether the source plant was transgenic or nontransgenic (Table 2).

\section{DISCUSSION}

This work shows for the first time that expression of replicase coding sequences from RTSV confers resistance against the virus. While antisense (-) sequence derived from the Rep gene can confer a significant level of resistance (up to $60 \%$ resistant plants), positive $(+)$ sense constructs confer near immunity (100\% resistant plants) to RTSV infection.

The transformation protocol used enabled the regeneration of a large number of transgenic japonica rice plants of the variety TP309 (10), of which over $70 \%$ contained the Rep gene. As previously described (9), integration of single or multiple copies of the transgene usually occurred at one locus, as shown by genetic segregation of the gene. Expression of the Rep gene in either orientation did not affect the development of the plantlets. This contrasted with the situation in bacteria, because all of our attempts to clone the full Rep gene in a bacterial expression vector failed (33).

The level of resistance to RTSV in plants expressing the antisense sequence of the Rep gene was moderate (60\% noninfected plants) (Table 1), and accumulation of the transgene RNA was substantial (Fig. 2). No symptom recovery was observed as is sometimes the case in resistance induced via a cosuppression mechanism $(17,32)$, indicating that resistance in this case is, therefore, via direct RNA-mediated resistance. One can postulate that the
RNA transcript interacted with the viral RNA and interfered with normal replication and translation $(4,5)$. However, we did not observe a correlation between the level of accumulation of (-)-sense Rep RNA and resistance, as was reported for geminiviruses $(6,14)$.

Plants expressing the Rep gene in the sense orientation exhibited characteristics of homology-dependent resistance: a very high level of resistance to RTSV even in the presence of high inoculum levels (high number of GLH) and low levels of transgene transcript. Plants expressing the intact, nonmutated Rep gene, as well as those expressing a truncated form of the gene, were highly resistant to virus inoculation, providing further support for RNA-mediated resistance. It would appear that, in the case of Rep protein-mediated

TABLE 2. Transmission of rice tungro bacilliform virus (RTBV) by green leafhoppers $(\mathrm{GLH})$ from different transgenic source plants, rice tungro spherical virus (RTSV) infected or not ${ }^{\mathrm{a}}$

\begin{tabular}{|c|c|c|c|c|c|}
\hline \multirow[b]{3}{*}{ Lines } & \multirow{2}{*}{\multicolumn{3}{|c|}{ Transgenic source plants }} & \multicolumn{2}{|c|}{ RTBV transmission ${ }^{b}$} \\
\hline & & & & \multirow{2}{*}{$\begin{array}{c}\text { Virus-free } \\
\text { GLH }\end{array}$} & \multirow{2}{*}{$\begin{array}{l}\text { RTSV } \\
\text { GLH }^{c}\end{array}$} \\
\hline & Plant no. & RTSV & RTBV & & \\
\hline \multicolumn{6}{|c|}{ Replicase sense 147.4} \\
\hline & 1 & - & + & - & nd \\
\hline & 2 & - & + & - & + \\
\hline & 3 & - & + & - & nd \\
\hline \multicolumn{6}{|c|}{ Replicase sense 147.8} \\
\hline & $1^{\mathrm{d}}$ & + & + & + & nd \\
\hline & 2 & - & + & - & nd \\
\hline & 3 & - & + & - & nd \\
\hline & 4 & - & + & - & + \\
\hline & 5 & - & + & - & nd \\
\hline \multicolumn{6}{|c|}{ Truncated replicase 147.3} \\
\hline & 1 & + & + & + & nd \\
\hline & 2 & - & + & - & + \\
\hline & 3 & - & + & - & nd \\
\hline & 4 & - & + & - & nd \\
\hline \multicolumn{6}{|c|}{ Replicase antisense 146.6} \\
\hline & 1 & + & + & + & nd \\
\hline & 2 & - & + & - & + \\
\hline
\end{tabular}

a GLH fed overnight on these source plants for virus acquisition and were placed afterwards on TN1 for inoculation. RTBV transmission (RTBV infection of these TN1 plants) was recorded.

b Measured by enzyme-linked immunosorbent assay 14 days after inoculation on TN1 by three GLH.

${ }^{c}$ GLH have been previously fed overnight on RTSV-infected TN1. nd = Not determined.

${ }^{\mathrm{d}}$ Polymerase chain reaction-negative segregant.

TABLE 1. Infectivity assay of rice tungro spherical virus (RTSV) replicase transgenic rice lines challenged with RTSV after inoculation with green leafhoppers

\begin{tabular}{|c|c|c|c|c|c|c|}
\hline \multirow[b]{2}{*}{ Transgenic plant lines } & \multicolumn{2}{|c|}{15 days after first inoculation } & \multicolumn{2}{|c|}{12 days after second inoculation } & \multicolumn{2}{|c|}{35 days after second inoculation } \\
\hline & Susc/inoc ${ }^{\mathrm{a}}$ & $\% \mathrm{R}^{\mathrm{b}}$ & Susc/inoc & $\% \mathrm{R}$ & Susc/inoc & $\% \mathrm{R}$ \\
\hline 146.1 & $5 / 12$ & 58 & $12 / 12$ & 0 & $12 / 12$ & 0 \\
\hline 146.1 PCR_c & $1 / 1$ & 0 & $1 / 1$ & 0 & $1 / 1$ & 0 \\
\hline NTTP309d & $8 / 12$ & 33 & $12 / 12$ & 0 & $12 / 12$ & 0 \\
\hline 146.6 & $0 / 18$ & 100 & $7 / 18$ & 61 & $10 / 18$ & 44 \\
\hline 146.6 PCR- & $5 / 7$ & 29 & $7 / 7$ & 0 & $7 / 7$ & 0 \\
\hline NTTP309 & $5 / 5$ & 0 & $5 / 5$ & 0 & $5 / 5$ & 0 \\
\hline 146.7 & $10 / 19$ & 47 & $19 / 19$ & 0 & $19 / 19$ & 0 \\
\hline 146.7 PCR- & $4 / 7$ & 43 & $7 / 7$ & 0 & $7 / 7$ & 0 \\
\hline NTTP309 & $8 / 12$ & 33 & $12 / 12$ & 0 & $12 / 12$ & 0 \\
\hline 147.3 & $0 / 9$ & 100 & $0 / 9$ & 100 & $0 / 9$ & 100 \\
\hline NTTP309 & $5 / 5$ & 0 & $5 / 5$ & 0 & $5 / 5$ & 0 \\
\hline 147.4 & $0 / 22$ & 100 & $0 / 22$ & 100 & $0 / 22$ & 100 \\
\hline NTTP309 & $5 / 7$ & 28 & $7 / 7$ & 0 & $7 / 7$ & 0 \\
\hline 147.8 & $0 / 16$ & 100 & $0 / 16$ & 100 & $0 / 16$ & 100 \\
\hline 147.8 PCR- & $8 / 8$ & 0 & $8 / 8$ & 0 & $8 / 8$ & 0 \\
\hline NTTP309 & $8 / 12$ & 33 & $12 / 12$ & 0 & $12 / 12$ & 0 \\
\hline
\end{tabular}

Susc/inoc = susceptible plants (positive in enzyme-linked immunosorbent assay) per total number of plants inoculated by viruliferous green leafhoppers.

ob $\mathrm{R}=$ percentage of plants free of virus.

$\mathrm{PCR}-=$ polymerase chain reaction-negative segregants (offspring plants without transgene).

NTTP309 = control, nontransformed TP309. 
resistance, for some viruses, an active Rep has to be expressed (potato virus Y [2] and tobacco mosaic virus [8]), and for some others, the Rep has to be defective (alfalfa mosaic virus [7,28]).

Interestingly, although all 19 challenged plants from the plant line expressing the truncated Rep (147.3) were found to be resistant when tested against RTSV alone, one plant became infected with RTSV and RTBV when inoculated with both viruses. This phenomenon was not observed for the two other plant lines that expressed the whole Rep gene. They never became infected by RTSV even in the case of a mixed inoculation. It is known that a synergism exists between RTSV and RTBV (23) that seems to correlate with virus content (12), but the underlying molecular mechanisms are still unknown. We have observed that transgenic rice expressing RTBV sequences do affect RTSV accumulation (A. de Kochko, unpublished data), suggesting some molecular interactions between the two viruses. The data presented here do not confirm whether the infection of line 147.3 by RTSV is really the consequence of coinoculation with RTBV. Similarly, we do not know if the fact that it happened only in the line expressing truncated and not the full-length Rep gene is meaningful. Determining this may lead to a better understanding of the molecular features of rice tungro disease. Furthermore, it is of practical importance because, in tungro disease-contaminated fields, both viruses are present, although infection by RTSV alone precedes infection by both viruses.

The Rep gene was cloned from a RTSV isolate from the Philippines. When expressed as a transgene in rice, it conferred high resistance against distinct and geographically distant Malaysian isolates. The percentage of homology between Rep sequences of the Malaysian and Filipino isolates has not been determined because the Malaysian isolates are yet to be molecularly characterized. However, these data on resistance show that the use of a Rep gene from the Philippines can confer resistance to RTSV in different areas of the Malaysia peninsula and Borneo and suggest that the imported resistance might not be strain specific.

From an agronomic point of view, RTSV enhances the severity of the tungro disease; a field of RTSV-resistant plants would certainly have reduced yield loss due to tungro disease when compared with losses in susceptible plants. However, our goal is mostly to use RTSV-resistant rice for an epidemiological approach (to stop or at least considerably slow down the spread of the disease). It is well documented that RTSV is required for RTBV transmission; in order to transmit RTBV, GLH have to feed on mixed RTBVand RTSV-infected plants or feed on RTSV-infected plants before feeding on RTBV-infected plants (23). Existence of a helper component other than RTSV virions has previously been shown (21, 22). Our data confirmed that RTSV-resistant transgenic rice did not permit RTBV transmission and, therefore, ruled out the possibility that a low titer of virus particles (below ELISA detection) or the transgene-encoded protein in the transgenic resistant plant could allow RTBV transmission. In the only report concerning the epidemiological effects of transgenic plants, Thomas et al. (34) showed that transgenic potatoes only moderately resistant to potato leaf roll luteovirus greatly limited spread of the virus by the aphid vector. Although this example is somewhat different from the tungro disease, it provides encouraging information because, in both cases, secondary infection plays a major role in the epidemiology of the viral disease.

The current report, in combination with a previous paper describing coat protein-mediated RTSV resistance (31), shows that RTSVresistant rice obtained by genetic engineering is now a reality. A survey in the Philippines revealed that RTSV is widespread (3) in that country, and that may be the situation in all of southeast Asia. The constant presence of RTSV may explain the sudden and unexpected outbreaks of tungro disease when subsequent infection by RTBV occurs. Furthermore, a disease called rice waika disease seriously affected rice in Japan in the 1970s. It was found to be due to an extreme susceptibility of a particular rice cultivar to a specific strain of RTSV $(16,30)$, demonstrating that RTSV has the potential to be a damaging virus by itself. Production of RTSV-resistant rice may, therefore, be beneficial. Field experiments, preferably in several geographic locations where tungro disease is endemic, are now required to assess the effectiveness of the RTSV replicasemediated resistance.

\section{ACKNOWLEDGMENTS}

We thank The Rockefeller Foundation and IRD (Institut de Recherche pour le Développement, formerly ORSTOM) for financial support to ILTAB/IRD-DPSC, United States, and MARDI, Malaysia. We also thank S.-J. Leitner for greenhouse care, J.-P. Brizard for technical assistance, and $\mathrm{N}$. Taylor for reviewing the manuscript and numerous suggestions.

\section{LITERATURE CITED}

1. Anjaneyulu, A., Satapathy, M. K., and Shukla, V. D. 1995. Rice Tungro. Sci. Publ. Inc., Lebanon, NH.

2. Audy, P., Palukaitis, P., Slack, S. A., and Zaitlin, M. 1994. Replicasemediated resistance to potato virus $\mathrm{Y}$ in transgenic plants. Mol. PlantMicrobe Interact. 7:15-22

3. Bajet, N. B., Aguiero, V. M., Daquioag, R. D., Jonson, G. B., Cabunagan, R. C., Mesina, E. M., and Hibino, H. 1986. Occurrence and spread of rice tungro spherical virus in the Philippines. Plant Dis. 70:971-973.

4. Baulcombe, D. C. 1996. Mechanisms of pathogen-derived resistance to viruses in transgenic plants. Plant Cell 8:1833-1844.

5. Beachy, R. N. 1997. Mechanisms and applications of pathogen-derived resistance in transgenic plants. Curr. Opin. Biotechnol. 8:215-220.

6. Bendahmane, M., and Gronenborn, B. 1997. Engineering resistance against tomato yellow leaf curl virus (TYLCV) using antisense RNA. Plant Mol. Biol. 33:351-357.

7. Brederode, F. T., Taschner, P. E. M., Posthumus, E., and Bol, J. F. 1995. Replicase-mediated resistance to alfalfa mosaic virus. Virology 207:467-474.

8. Carr, J. P., Marsh, L. E., Lomonossoff, G. P., Sekiya, M. E., and Zaitlin, M. 1992. Resistance to tobacco mosaic virus induced by the 54-kDa gene sequence requires expression of the 54-kDa protein. Mol. Plant-Microbe Interact. 5:397-404.

9. Chen, L., Marmey, P., Taylor, N. J., Brizard, J.-P., Espinoza, C., D’Cruz, P., Huet, H., Zhang, S., de Kochko, A., Beachy, R. N, and Fauquet, C. M. 1998. Expression and inheritance of multiple transgenes in rice plants. Nature Biotechnol. 16:1060-1064.

10. Chen, L., Zhang, S., Beachy, R. N., and Fauquet, C. 1998. A protocol for consistent, large scale production of fertile transgenic rice plants. Plant Cell Rep. 18:25-31.

11. Church, G. M., and Gilbert, W. 1984. Genomic sequencing. Proc. Natl. Acad. Sci. U.S.A. 81:1991-1995.

12. Dahal, G., and Hibino, H. 1985. Relative amounts of tungro (RTV)-associated viruses in selected rices and their relation to RTV symptoms. Int. Rice Res. Newsl. 10:10-11.

13. Dahal, G., Hibino, H., Cabunagan, R. C., Tiongco, E. R., Flores, Z. M., and Aquiero, V. M. 1990. Changes in cultivar reactions to tungro due to changes in "virulence" of the leafhopper vector. Phytopathology 80:659665.

14. Day, A. G., Bejarano, E. R., Buck, K. W., Burrell, M., and Lichtenstein, C. P. 1991. Expression of an antisense viral gene in transgenic tobacco confers resistance to the DNA virus tomato golden mosaic virus. Proc. Natl. Acad. Sci. U.S.A. 88:6721-6725.

15. Dellaporta, S. L., Wood, J., and Hicks, J. B. 1983. A plant DNA minipreparation: Revision II. Plant Mol. Biol. Rep. 1:19-21.

16. Furuta, T. 1977. Rice waika, a new virus disease, found in Kyushu, Japan. Rev. Plant Prot. Res. 10:70-82.

17. Guo, H. S., and Garcia, J. A. 1997. Delayed resistance to plum pox potyvirus mediated by a mutated RNA replicase gene: Involvement of a gene-silencing mechanism. Mol. Plant-Microbe Interact. 10:160-170.

18. Haffner, M. H., Chin, M. B., and Lane, B. G. 1978. Wheat embryo ribonucleates. XII. Formal characterization of terminal and penultimate nucleoside residues at the $5^{\prime}$ ends of "capped" RNA from imbibing wheat embryos. Can. J. Biochem. 56:729-733.

19. Hellwald, K. H., and Palukaitis, P. 1995. Viral RNA as a potential target for two independent mechanisms of replicase-mediated resistance against cucumber mosaic virus. Cell 83:937-946.

20. Herdt, R. W. 1991. Research priorities for rice biotechnology. Pages 1954 in: Rice Biotechnology. G. S. Kush and G. T. Toenniessen, eds. CAB International, Wallingford, United Kingdom.

21. Hibino, H. 1983. Relations of rice tungro bacilliform and rice tungro spherical viruses with their vector Nephottetix virescens. Ann. Phytopathol. Soc. Jpn. 49:545-553.

22. Hibino, H., and Cabauatan, P. Q. 1987. Infectivity neutralization of rice 
tungro-associated viruses acquired by vector leafhopper. Phytopathology 77:473-476.

23. Hibino, H., Roechan, M., and Sudarisman, S. 1978. Association of two types of virus particles with penyakit habang (tungro disease) of rice in Indonesia. Phytopathology 68:1412-1416.

24. Koonin, E. V. 1991. The phylogeny of RNA-dependent RNA polymerases of positive-strand RNA viruses. J. Gen. Virol. 72:2197-2206.

25. Ling, K. C., Tiongco, E. R., and Flores, Z. M. 1983. Epidemiological studies of rice tungro. Pages 249-251 in: Plant Virus Epidemiology. R. T. Plumb and J. M. Tresh, eds. Blackwell Scientific Publications, Oxford.

26. Mueller, E., Gilbert, J. E., Davenport, G., Brigneti, G., and Baulcombe, D. C. 1995. Homology-dependent resistance: Transgenic virus resistance in plant related to homology-dependent gene silencing. Plant J. 7:1001-1013.

27. Ou, S. H. 1985. Rice Diseases. CAB International, Wallingford, United Kingdom.

28. Palukaitis, P., and Zaitlin, M. 1997. Replicase-mediated resistance to plant virus disease. Adv. Virus Res. 48:349-377.

29. Shen, P., Kaniewska, M., Smith, C., and Beachy, R. N. 1993. Nucleotide sequence and genomic organization of rice tungro spherical virus. Virology 193:621-630.
30. Shinkai, A. 1977. Rice waika, a new virus disease, and problem related to its occurrence and control. Jpn. Agric. Res. Q. 11:151-155.

31. Sivamani, E., Huet, H., Shen, P., Ong, C. A., de Kochko, A., Fauquet, C., and Beachy, R. N. 1999. Rice plants (Oryza sativa L.) containing Rice tungro spherical virus (RTSV) coat protein transgenes are resistant to virus infection. Mol. Breed. 5(2):177-185.

32. Tenllado, F., Garcia-Luque, I., Serra, M. T., and Diaz-Ruiz, J. R. 1995. Nicotiana benthamiana plants transformed with the 54-kDa region of the pepper mild mottle tobamovirus replicase gene exhibit two types of resistance responses against viral infection. Virology 211:170-183.

33. Thole, V., and Hull, R. 1998. Rice tungro spherical virus polyprotein processing: Identification of a virus-encoded protease and mutational analysis of putative cleavage sites. Virology 247(1):106-114.

34. Thomas, P. E., Kaniewski, W. K., and Lawson, E. C. 1997. Reduced field spread of potato leafroll virus in potatoes transformed with the potato leafroll virus coat protein gene. Plant Dis. 81:1447-1453.

35. Tiongco, E. R., Cabauatan, P. Q., Flores, Z. M., Hibino, H., and Koganezawa, H. 1993. Serological monitoring of rice tungro disease development in the field: Its implication in disease management. Plant Dis. 77:877-882. 